\title{
NATO Enlargement: A „Geopolitical Victory"of the United States in the Post-Cold War Era? Results and Perspectives
}

\author{
Petar Kurečić
}

The Post-Cold War enlargement of NATO, in two rounds so far, was the biggest and the most important geopolitical change in Europe, after the geopolitical transition that took place in Europe from 1989 to 1991. A third round of the enlargement, which includes Croatia and Albania, was opened at the NATO summit in Bucharest in April 2008, by sending invitations to these two states. Enlargement was and still is a part of NATO's transformation in the Post-Cold War Era in which NATO has evolved from a traditional form of military-political alliance into a combination of an alliance and security community. It also was and still is an expression of American triumph in the Cold War and the rising of the USA to a status of the world's only superpower. NATO has enlarged its territorial reach, changed its missions, capabilities and objectives, and is continuing to modify them so that it could stay prepared for the future security challenges facing its members. The biggest challenge facing NATO in the future may be coming from the inside - the possibility of becoming a tool of USA's global geostrategy and its aims. If NATO wants to remain a legitimate alliance and develop itself towards the security community, it must not become a tool for fulfilling the geopolitical and geostrategic goals of only one state, not even the USA. Therefore, a balanced approach in American-European relations is needed, according to which the USA would not use its military power to impose its geopolitical and geostrategic objectives at any cost.

Key words: NATO, geopolitical objectives, geostrategic objectives, Post-Cold War Era, United States of America, Europe

\section{Proširenje NATO-a: Geopolitička pobjeda SAD-a u post hladnoratovskom razdoblju? Rezultati i perspektive}

Post hladnoratovsko proširenje NATO-a, u dosad provedena dva kruga, predstavlja najveću i najvažniju geopolitičku promjenu u Europi, nakon geopolitičke tranzicije koja se u Europi odigrala u razdoblju od 1989. do 1991. g. Treći krug proširenja, koji uključuje Hrvatsku i Albaniju, otvoren je davanjem pozivnica ovim državama na Summitu NATO-a u Bukureštu u travnju 2008. g. Proširenje je bilo i još uvijek jest dio preobrazbe NATO-a u post hladnoratovskom razdoblju u kojem je NATO evoluirao iz tradicionalnog vojnopolitičkog saveza u kombinaciju saveza i sigurnosne zajednice. Proširenje je također bilo i jest izraz američke pobjede u hladnom ratu i uzdizanja SAD-a u jedinu svjetsku supersilu. NATO je povećao svoj teritorijalni obuhvat, promijenio svoje misije, sposobnosti i ciljeve, te ih nastavlja mijenjati kako bi ostao spreman odgovoriti na buduće sigurnosne izazove koji se postavljaju pred njegove članice. Najveći izazov NATO-u u budućnosti mogao bi doći iznutra, a to je mogućnost da postane sredstvo američke globalne geostrategije i njenih 
ciljeva. Ako NATO želi ostati legitimnim savezom i izrastati u sigurnosnu zajednicu, ne smije postati sredstvo za ispunjavanje geopolitičkih i geostrateških ciljeva samo jedne države, pa čak ni SAD-a. Stoga je u odnosima SAD-a i Europe potreban uravnotežen pristup, prema kojem SAD ne bi koristile vojnu moć kako bi nametale svoje geopolitičke i geostrateške ciljeve pod svaku cijenu.

Ključne riječi: NATO, geopolitički ciljevi, geostrateški ciljevi, post hladnoratovsko razdoblje, Sjedinjene Američke Države, Europa

\section{INTRODUCTION}

The North Atlantic Treaty Organization (NATO, as we will refer to it in this article), has continued its existence in the Post-Cold War Era, as a subject i.e. player in the new geopolitical world-order, as a combination of military alliance and security community. The main cause of NATO's founding and existence for forty years since its founding, The Warsaw Treaty had been dissolved (formally signed in 1955, but the communist bloc existed in 1949, when NATO was founded) in 1991. But NATO continued to exist, and it continued to enlarge its membership, at the same time transforming itself to adapt to the new conditions in the international arena. What is more important, it has continued to fulfill its missions, especially the new ones. This fact could be considered surprising, if we did not know that NATO's members thought it was more useful and efficient to keep NATO alive, than to dissolve it.

The Soviet Union, which ceased to exist in 1991, lost control of Central and Eastern Europe, even before it dissolved. The Warsaw Treaty was formally dissolved in 1991; the communist ideology was no longer the ruling ideology in the states that used to be parts of the Eastern bloc. The threat of total nuclear warfare was brought from a considerable to a minimal certainty. The successor states of the former Soviet Union were not nearly as powerful, as the former Soviet Union at the peak of its power. Also, they were not hostile toward NATO. Russia had a lot of internal economic, political and economic problems during the whole nineties. It needed all the help it could get from the West, as well as other states that evolved after the dissolution of the Soviet Union. The USA remained the only superpower, and a completely new era of geopolitical and international relations has evolved. Anew geopolitical world-order, as we call it, since it has not been named properly, started to evolve. It could be called an American geopolitical world-order, because of the overwhelming predominance of the USA in geopolitical, geostrategic and geoeconomic relations. The new world-order is marked by globalization and a predominance of market economy. All the changes that we have mentioned were powerful factors that could have brought the purpose of NATO's existence into question.

\section{THE DEBATES ABOUT NATO'S FUTURE}

At that time, parts of the academic community and public opinion considered NATO to be a relic of the Cold War Era, and made public appeals to politicians to dissolve NATO. They believed that the new system of Euroatlantic security should be established around 
the Organization (then Conference) for Security and Cooperation in Europe. Contrary to this, at the time of the dissolution of Warsaw Treaty, every opinion that considered the further existence of NATO redundant, did not find any substantiating support among the political elites of NATO members. The reasons were various. The unification of Germany and its continued membership as a unified country was a huge political victory for NATO and a first pointer that the victory in Cold War is possible and close. New threats and challenges occurred in Central, Eastern and especially Southeastern Europe after the dissolution of the Warsaw Pact, Soviet Union and Yugoslavia. By this, we refer to ethnic hatred, ethnic conflicts and territorial disputes which were suppressed for a long time. As a consequence, areas of violence and instability occurred in the former Soviet Union and in former Yugoslavia. In most cases, economic crises and the instability of just recently established and weak institutions, which were not following democratic standards, caused the risk of internal chaos and international conflicts to become very real. Besides that, Russia became a huge problem, a nuclear superpower, torn by internal instability, whose economy was ruined, and the living standard of Russian nation plummeted. The perception of Russia as a threat to security was that Russia posed no military threat to the security of the West. However, Central and East European states perceived Russia as a threat, due to geographical proximity and painful experiences from the past. When the Eastern bloc ceased to exist, Poland and the three Baltic states especially, found themselves in a security vacuum, without any institutionalized security arrangements. Therefore, they wanted and needed security guarantees from NATO, as full members of the Alliance, as a guarantee towards a possible Russian neo-imperialism. (Brzezinski 1998)

Debates that were conducted in the scientific communities and among the political elites of the NATO member states concluded that NATO was best prepared for the whole spectrum of security threats that the West was facing in the Post-Cold War Era. However, that does not mean that the enlargement did not suffer strong opposition among the intellectual elites of the West, especially in the USA. They thought that enlargement will only antagonize Russia, that the Russian new nationalism and imperialism will grow stronger because of NATO's march to the East and that the new members cannot bring any more security to the Alliance. Enlargement faced a strong opposition from both liberal institutionalists and from conservative realists, which represent both sides of the spectrum of international relations theories. Of course, each group had different reasons for opposing the enlargement, but in the focus of both opinions was Russia as a nuclear superpower and a super problem that needs to be dealt with special care. (Mandelbaum 1995, Brown 1995)

The opinion that prevailed after a long and profound debate, and later became a mainstream opinion and doctrine of NATO, was: The new era brings with itself new challenges which demand the new missions, but NATO has every reason to continue its existence. The events that occurred during the geopolitical transition, from 1989 to 1991, after the fall of communism in Eastern Europe gave confirmation of their beliefs to those who thought that NATO should survive and the members were more secure if they continued to be members of NATO. However, the opinion that NATO should transform itself in accordance with new challenges and conditions, also found its ground. (Weber 1992, Risse-Kappen 1996) 
At the beginning of Clinton's first term as President of the USA, people who did not share his beliefs about NATO enlargement represented a majority of the Administration. They thought that the policy towards Russia was more important and that this was of primary foreign national interest of the USA. They believed that even a plan to enlarge NATO would have made undemocratic tendencies in Russia stronger, and made organized opposition towards the West among the strongest political power in Russia. (Carter, Perry 1999)

Opponents to NATO enlargement were also present in the State Department, and they thought that NATO was so far the most important success of American policy in Europe. The enlargement would increase its responsibilities, and would not increase its capabilities. Besides, European allies were not perceived to be very interested in enlargement. (Asmus 2002)

In opposition to those who wanted to avoid the debate about enlargement, there were the supporters of the enlargement who wanted a public debate to take place. They thought that the enlargement was part of a broader transformation of the Alliance in accordance with the new challenges and new mission. The importance of the US role in NATO was a key factor for the enlargement, and the public debate was going on in the USA.

\section{CHALLENGES TO THE ENLARGEMENT - INFLUENCE OF THE EUROPEAN UNIFICATION AND BALKAN WARS}

Besides the challenges that were brought in front of NATO as a result of the geopolitical, geostrategic and geoeconomic changes in Europe and the World, the problem of defining internal relations among the members of NATO and the relationship between NATO and the EU was significant for the future of NATO, the EU, transatlantic relations, European and Euroatlantic security. The biggest internal problem, like many times before in the history of NATO, was the relationship between the USA (which always had the support of Great Britain) and France and to some degree Germany. The enemy that was the cause of founding the Alliance and its survival during the four decades of the Cold War was gone. Geostrategic relations had changed irreversibly, and this change had brought the survival of NATO in question. This change also signified the basics of NATO's complete transformation, which started at the end of the geopolitical transition, as a reaction to the beginning of new era in international relations and a new geopolitical world-order.

Transformation of NATO as a main goal of the Alliance can be found in all the official documents from NATO Summits, from the Summit of Rome in 1991, to the Summit of Riga, held in 2006. The enlargement was one of the elements of transformation of NATO itself, and it is also one of the main geopolitical and geostrategic objectives of NATO. Part of this transformation was a significant reduction of NATO's defense spending and defense spending of every NATO member. But before the enlargement could start, NATO had to show that it was capable to function in the new geostrategic relations, and that it was able to shape the new security architecture in Europe and its border regions. At the same time it had to adapt itself to the new strategic and political conditions. (Cornish 1996)

In accordance with the cooperation of NATO and the EU, NATO enlargement posed and continues to pose substantial implications for the EU. Out of 27 members of the EU 
and 26 members of NATO, 21 states are members of both organizations. If we take into account that two NATO member states are geographically located in North America, and Turkey as a NATO member state also wants to join the EU for a long time, we can see that membership in NATO and the EU is a complementary issue. All states of the former Eastern bloc that joined NATO so far have joined the EU.

The influence of wars in the Balkans was also significant for NATO's transformation. Wars in former Yugoslavia were perceived as a renewal of old, medieval conflicts and hatred, which resurfaced after the collapse of geopolitical stability and balance of power in Europe. All these conflicts were fought at the borders of unified and wealthy Europe. The conflict that showed how powerless NATO was, and did not act to stop the bloodshed in Europe, was the conflict in former Yugoslavia. NATO could have drawn the line; it could have given guarantees against the violent change of political borders in the Eastern and Southeastern Europe. NATO could have given guarantees to the states that were already under attack and to those who faced the possibility of an attack, because of the ethnic hatred and geopolitical rivalries between some of the newly independent states in Europe. NATO was the only organization capable of giving such a guarantee, which was difficult to achieve politically, but it was militarily achievable, since NATO is a real military force of Europe.

It is interesting that NATO, at the Rome Summit in 1991, originally did not find it necessary to mention the situation in Yugoslavia, which was breaking apart in the biggest war in Europe since the Second World War. NATO perceived the war in Croatia as an internal conflict outside its borders, which should not involve NATO's engagement. Of course, this attitude was completely contrary to NATO's objective to become one of the pillars of European security, which should be indivisible. NATO members finally accepted a declaration at the Rome summit on November 8, just ten days before Vukovar was destroyed and occupied by Serbian troops. Declaration did not state a condemnation of violence and war crimes committed in Croatia. This fact shows that the great powers had their political interests that did not allow the internationalization of Serbian aggression against Croatia. Since every decision in NATO must be reached by consensus, there was no possibility that NATO would intervene. These wars broke all international conventions and conventions of civilized political action, and seriously damaged the confidence in the future of peaceful international relations, which seemed justified after the end of bipolarism. It has broken the political unity of Europe and clouded the achievements of political cooperation in the West.

The possibility that international order and cooperative relations could be transferred and introduced to the east of Europe, and even onto the states of the former USSR did not seem unrealistic at the beginning of the nineties. But the wars in the Balkans jeopardized this possibility. Presumption that the war and cruelty were something that was natural for the Balkans influenced the USA and the West in a sense that they did not want to get involved in war. By doing this, they were indirectly involved in ethnic cleansing (Pfaff, 1993)

All peace plans practically legalized ethnic cleansing. And the risk that Albania and Hungary would find themselves involved in the war was not negligible. It took NATO three years to intervene in Bosnia, but it was an intervention that was, from the military aspect, unimportant. If it were not for the Croatian victories in 1995, the political map 
of the Balkans would look very different than it looks today. Bosnia was stabilized after the Croatian victories and weak interventions of NATO, which allowed the genocide in Srebrenica to occur. But Bosnia was not given the prospects for normal functioning and a stable future. It still represents a state of three nations that do not want to live together, and Bosnian Serbs are pushing for a referendum on separation from Bosnia and Herzegovina and they want to proclaim their own state. Kosovo proclaimed its independence on February 17, 2008, nine years since NATO's military intervention successfully stopped ethnic cleansing done by Serbian troops against Albanians in Kosovo. Serbia is, and it probably will, for a long time, be unsuccessfully dealing with the complete loss of Kosovo. NATO's intervention against Serbia in 1999 finally showed that NATO actually was accountable as one of the pillars of European security. It was a first out-of-area operation conducted by NATO, and it showed various possibilities of NATO's actions.

\section{GEOPOLITICAL AND MILITARY PREDOMINANCE OF THE USA AND ITS INFLUENCE ON NATO'S ENLARGEMENT}

After the breakup of the USSR, the USA remained the only superpower. A completely new era of geostrategic relations has begun. A new geopolitical world-order started to develop, around the predominance of the USA, so maybe we could call it the American geopolitical world-order. The USA never seriously considered the possibility of NATO's dissolution. Since the American vote in NATO usually was worth as much as all the other votes together, NATO's future was secure. The administration of President Bush senior decided that it would continue to be actively involved in the European affairs, so it continued the US political and military presence in Europe. Since the beginning, and especially from the middle of the nineties, appeals for the downsizing of US presence in Europe and more substantial involvement of Europeans in the projection of power started. That also meant transferring the burden of responsibility on Europe. We can also say that NATO enlargement would not have happened if it was not for Clinton's administration and its will to enlarge NATO. All the key decisions which made even the debate about the possible enlargement possible, and the decisions that brought the first round of enlargement into being were made during the Clinton administration and were the result of the President's will. The second round of the enlargement was simply a next logical step, like the third round of enlargement that started at the NATO Summit in Bucharest with invitations to Croatia and Albania to join the Alliance is the present logical step. The process is more and more becoming a sort of routine. But the first round and the initiative that came from the administration of the USA at that time were a factor that broke the deadlock and changed NATO from a Cold War military alliance toward a Post-Cold War security community.

At the beginning of the nineties, NATO was falling into a crisis, so it needed a change. It needed a strategy that would be capable of responding to challenges outside the borders of Western Europe, in the areas where regional problems were getting more and more difficult. The USA, as the only power that is capable of projecting and exerting strategic power, gave its allies the opportunity to enjoy these benefits without the real burden sharing. The use of NATO as a mechanism for the defense of Western interests was planned so that US allies would start to prepare for their projection of military power. This was 
planned so that NATO would become capable for the exertion of power in the regions that were not in the reach of the Alliance before. These regions are Eastern Europe, Caucasus, Central Asia and the Persian Gulf. (Gompert, Kugler 1995)

However, the situation has not changed over the years, since the USA gave about 90 percent of coalition troops in both Iraqi wars, in 1991 and 2003. We can conclude that US military predominance and European lack of capability to follow the USA in military spending and development continue to be a constant fact of transatlantic relations.

\section{THE INFLUENCE OF NATO ENLARGEMENT ON THE NEW MEMBERS}

NATO encountered two enlargements in the Post-Cold War Era, accepting ten new members, former communist states and former Soviet republics. The first round of enlargement, in 1999, included three Central European states, Czech Republic, Hungary and Poland. NATO membership grew from 16 to 19 states. The second round included seven states - Bulgaria, Estonia, Latvia, Lithuania, Romania, Slovakia and Slovenia. Membership of NATO rose from 19 to 26 states. The second round of enlargement brought NATO on Russian borders and established direct territorial contact between Hungary and rest of the Alliance. Greece and Turkey, across Bulgaria and Romania, were connected with the rest of the Alliance territory in Central Europe. NATO members surrounded the unstable region of the Western Balkans after the second round of enlargement.

Tab. 1 Territory and population of ten new NATO members

Tab 1. Teritorij i stanovništvo deset novih članica NATO-a

\begin{tabular}{|c|c|c|}
\hline NATO member state & Territory in square km & $\begin{array}{c}\text { Population in 000 } \\
\text { (July 2007 est.) }\end{array}$ \\
\hline Bulgaria & 110910 & 7323 \\
\hline Czech Republic & 78866 & 10229 \\
\hline Estonia & 45226 & 1316 \\
\hline Hungary & 93030 & 9956 \\
\hline Latvia & 64589 & 2260 \\
\hline Lithuania & 65200 & 3575 \\
\hline Poland & 312685 & 38518 \\
\hline Romania & 237500 & 22276 \\
\hline Slovakia & 48845 & 5448 \\
\hline Slovenia & 20273 & 2009 \\
\hline New NATO members & $\mathbf{1 0 7 7} \mathbf{1 2 4}$ & $\mathbf{1 0 2} \mathbf{9 1 0}$ \\
\hline
\end{tabular}

Reference: https:// www.cia.gov/library/publications/the-world-factbook/index.html

By accepting ten new members, NATO enlarged its territory, as Table 1 shows, for over a million square kilometers, and the population of its members grew by approximately 
103 million inhabitants. The two largest new member states, Poland and Romania, were responsible for about 55 percent of the territory and 60 percent of the population gained through the enlargement.

The enlargement was a part of the process of searching for new purpose of NATO, which was transforming itself from a military-political alliance whose primary purpose is territorial defense of its members to a security community that would act on the stabilization of the whole Eurasian area through new missions.

In the first half of the nineties, four states became front-runners for the possible NATO membership, if the enlargement would take place. The Czech Republic, Hungary, Poland and Slovakia were these front-runners, and the reasons for this were historical: They were part of Central Europe, of the Austro-Hungarian Empire, they are Catholic states which were forcibly occupied by Russians, and they belonged to the Central European cultural heritage. The reasons were also geographical, since The Czech Republic and Poland border Germany which is a member of NATO, Hungary and Slovakia bordered former USSR and today they border Ukraine; Poland as a gateway state of the whole region represents a land bridge or gateway between Central and Eastern Europe, it borders Germany, Ukraine, Belarus, Lithuania and a Russian exclave, the province of Kaliningrad. Poland, because of geographical proximity and historical experience felt most threatened by the possibility of renewed Russian imperialism, which could have created a new zone of influence and political and economic pressure. The Czech Republic and Hungary also perceived NATO as the best way to accomplish their own security. NATO membership was also Slovakia's objective, although the support for this policy was lower than in the other three states. These four states together formed the Visegrad group, to promote their interests in front of the European and Euroatlantic institutions. The key factor of success for these four states was the position of the USA, as a leader of NATO. But, because of fears present in the West that focused on a new possible Russian imperialism, these states had to wait for more than five years, until 1997, when three states, except Slovakia, which was then under the authoritarian rule of Meciar, were invited to join NATO at the Madrid summit in July 1997.

The important geographical, strategic and political shift this enlargement, in two rounds, represented, brought this new NATO into the new Central Europe, into South Eastern Europe and beyond the borders of the former USSR, because the Baltic States became members. But this shift has a completely different meaning in this Post-Cold War Era than in the Cold War Era, when every shift from one side of the "Iron curtain" to another would meant almost certain possibility of continental, and possibly global nuclear war between the rival blocs. The geographical shift to the east and southeast of Europe puts NATO into a new position. It strengthens the northern, central and southern wing of NATO - if we can use this terminology today, when NATO on its new outer borders to the east ${ }^{1}$ borders the two states, Russia and Ukraine, which have cooperative relations with NATO of a different kind.

The enlargement gave NATO an opportunity to solve crises in their early stages. The enlarged NATO has a great military buildup and capabilities to intervene where it is necessary, before a crisis goes completely out of control. So we can state that NATO has greater possibilities for crisis management. The states of Central and Eastern Europe 
represent a good and reliable land bridge towards the regions where interventions are and could be necessary, on the large area from the Baltic over to the Black sea, Caucasus, and the Middle East. The strategic value of the new NATO members, especially Romania and Bulgaria, was confirmed when the USA decided to wage wars against the regimes in Afghanistan in 2001, and Iraq in 2003. US armed forces used the territory and air space of new NATO members.

Another significant gain that NATO got from the enlargement was a broader mission of building unified and stable European security architecture. Besides giving security guarantees to its new members, NATO has to help some European states that might not become members, but they could represent a very important strategic gain for NATO and the security of Europe. The best example is probably Ukraine ${ }^{2}$. This new, enlarged NATO is also more capable to develop relations of active partnership with Russia, and this partnership brings improvements in security cooperation, so that Europe can become and stay a stable environment, as much as it can be. NATO enlargement also introduced the possibility that democracy and other values from the West spread even further to the East, so that they could influence the regimes in the former USSR. The proof of this can be seen in the authoritarian regime changes in Georgia in 2003, Ukraine in 2004 and Kyrgyzstan in 2005. Besides that, the Partnership for Peace program gave an opportunity to those European states that wanted to remain neutral even after breakup of the Warsaw Treaty and were not its members, to participate in the European security architecture. For example, the neutral European countries: Austria, Finland, Ireland, Sweden and even Switzerland became members of the Partnership for Peace, and yet they never expressed a wish to become the members of NATO.

Central and Eastern Europe are so important for the security of Europe, that NATO would be forced to defend them, whether they were NATO members or not. Enlargement gave NATO a much better position in the defense of these states, with much less effort and spending. NATO membership also gave the states of Central and Eastern Europe an opportunity to reduce their defense spending, because when they became NATO members, they started to use security guarantees and benefits that the mighty Allies are giving them. By sending invitations to Albania and Croatia, at the Summit in Bucharest, in April 2008, NATO opened its door to the unstable region of Western Balkans.

\section{WHAT IS NATO TODAY BY ITS DEFINITION?}

To open a discussion about the character of NATO today, we pose a question: What is actually NATO today? Is NATO a political and military alliance, is it a security community of Anglo-American and European states that are its members, is it maybe an organization of indivisible Western, liberal and postnationalist interstate community? Or has it simply become a means for pursuit of American geopolitical and geostrategic goals, which are mainly oriented towards the control of oil reserves in the Middle East, Caspian Sea and Central Asia? The real character of today's NATO is probably somewhere in the middle.

NATO is, by its definition a political and military alliance, based on the collective defense of its members. It protects its members and their security in the transatlantic area. 
It has precisely defined the geographical area of its responsibility, which is written in the North Atlantic Treaty. But NATO in its new, out-of-area missions went out of the transatlantic area, and it conducts missions outside the territories of its members. Since it has started, through its security and partnership programs, to reach towards the non-member states (which are incorporated in Partnership for Peace, Mediterranean Dialogue, and partnership with Russia through Joint Council and Distinctive Partnership with Ukraine), NATO has become a sort of security community. So we can state that NATO is evolving, it functions through its evolution and change, which is permanent. It evolves as the geostrategic relations in the world change, and it adapts itself to the new security challenges.

If we define NATO as an organization of indivisible Western, liberal and post nationalistic interstate community, the following objections could be raised:

1) NATO is a regional organization. Liberal, Western identity is universal, but NATO, like the EU, has in its documents a defined territorial reach and area of responsibility, and will not enlarge over the defined borders. NATO does not want to become a unified liberal or Western community, since it is not its meaning or intention of its member states. The region that NATO focuses on by its membership is the North Atlantic i.e. transatlantic area, and by its missions it focuses on the area of Caucasus, Central Asia and the Middle East. But that does not influence its identity;

2) Regional identity is a second objection. NATO, besides European, includes the Anglo-American states - the USA and Canada, and the North Atlantic Ocean, and it represents the enlarged European i.e. Euroatlantic liberal community, and not the international community at large. NATO is the organization of European security, established with a purpose to defend Europe from Soviet threat. NATO is the main security organization of liberal Europe. The area that is included in the North Atlantic Treaty is the North Atlantic Ocean. The Pacific Ocean and the Caribbean Sea are not included, although they represent very important areas, regarding security, for the Anglo-American members of NATO. The North Atlantic Treaty claims that only European states can be invited into membership and the "Study on NATO Enlargement", one of the official key policy documents of NATO, accepted in 1995, stated that the possible enlargements would be conducted as one of the elements of broader evolution of European cooperation and security. The regional perspectives of NATO and the EU, regarding enlargement, are actually very similar, considering the area that they try to incorporate;

3) NATO is based on liberal norms and multilateralism, and it represents a typical interstate organization which functions on the principles of negotiating and agreements that leave the sovereignty of member states almost intact, so it is not a unified community;

4) Religious culture is the fourth objective, since NATO and the EU have their origins in the states whose societies belong to Western Christianity. Although there is a difference between Western and Eastern Christianity in Europe, and of course between Christianity and Islam, these lines of division are today not key factors of division in Europe, because NATO and the EU have, through their enlargements, overcome these dividing lines. Other criteria matter today. States 
that geographically belong to Europe, no matter what religion and culture they belong, have to fulfill the criteria that NATO and the EU put in front of them if they want to become members. By this we mean liberal values and norms. (Schimmelfennig 2003)

\section{THE REAL CHARACTER OF NATO: A TOOL FOR FULFILLMENT OF GEOPOLITICAL OBJECTIVES OF THE USA, OR A SECURITY COMMUNITY?}

By enlarging its territorial reach, and going "out-of-area" to the areas that are considered strategically important and that represent territories where security threats come from, NATO has fulfilled the geopolitical and geostrategic objectives of the USA and of some of its other members. But the real and more important question is: Has this change brought more or less security to NATO members than before? The other question that we have to ask and try to find the right answer is: Why has enlargement been so successful and why is a trend of further enlargement still present? This is a question that can not be answered with one argument. If we accept the basic presumption that NATO's foundations exist well beyond the military and defense area, the chances for its survival and long-term future seem much higher. The existing members and candidate countries want to use all the benefits from being part of this hegemonic alliance. They simply bandwagon and become the allies of the hegemon, which in this case is the USA. The high level of institutionalization brings benefits like stability of Europe, conflict prevention, crises management and coordination of national security policies. These benefits reach much further than geopolitical reasons. (Risse-Kappen 1995, 1996; Walt 1997)

However, if we want to understand NATO's persistence after the Cold War, we must turn to international institutionalist theories to explain why, contrary to neorealist expectations, NATO remains the key international security institution for its members. (McCalla 1996)

The mentioned views also have a strong opposition in form of views that identify a large degree of disagreements in the influence on decision-making process. The other argument they use is the shift in NATO's area of interest, and missions, which has shifted completely out-of-area in the regions of Caucasus, Central Asia and the Middle East. These areas are of the most important US strategic interest. The question that is important to ask here is: Are some Europeans using the current global policy of the USA so they could use the hegemon, which is under criticism for its action, to fulfill their strategic objectives, which are basically similar to those of the hegemon? Or is this opposition to American hegemony and establishment of control over the strategically important areas really authentic? Probably the truth lies somewhere in the middle, since we can not look at all the European allies through the same perspective. Smaller European states are using the American hegemonic position and security guarantees when they enter NATO, since neutrality would cost them at least three times more and they would not be using the security guarantees that NATO gives them.

Here we have to draw the line between NATO before and after September 11. We also have to draw the line between American global policies, whose goal of global lead- 
ership has become a pursuit for global hegemony with direct territorial control of strategically important areas, where the oil reserves are located, have started to fulfill after George W. Bush became President of the USA, and especially after September 11, in a sense that was unprecedented until then. The ways of fulfilling these goals have changed. They have become much more militaristic. (Kupchan 2002)

The degree of how much the USA is willing to go in fulfilling these goals has also changed, at the same time destroying the fragile stability of the Middle East. We also have to draw a distinction between justifiability of the intervention in Afghanistan and in Iraq, since the intervention in Iraq probably had nothing to do with the struggle against terrorism. (Johnson 2004) NATO's different views about these operations were shown in the inability to make decision by consensus and participate in the attack on Iraq in 2003, which was not the case with Afghanistan, where NATO is leading the ISAF, a stabilization force in Afghanistan.

However, we can say that commitments that were taken in Afghanistan and Iraq (by training Iraqi forces) are a result of a new consensus in NATO, which includes the shift of NATO's area of interest and shift in NATO's missions outside of Europe. It commits NATO to the development of capabilities, especially strategic, to be able to fulfill these kinds of missions. (Aybet 2004)

The new missions of NATO, which were in focus of the debates during the nineties, became especially important after September 11. Article 5, which is a core of the North Atlantic Treaty giving NATO the right to use collective defense ${ }^{3}$, became active for the first time in history. NATO proclaimed the state of war with terrorists that were responsible for the September 11 attacks. The main security challenges for NATO today are terrorism, proliferation and of course possible use of weapons of mass destruction, illegal drugs and human trafficking and ecological catastrophes. At present and in the near future, a conventional attack of large scale on any NATO member is highly unlikely. But these new security challenges can just as badly damage the territories of the member states, and hurt their population. What is really needed is a cooperation between all elements of security sectors of the member states and beyond that, involvement of all parts of society in giving support to the struggle against terrorism. The problem of dealing with these new security challenges is a problem of choosing between hard, military power and soft power, and the USA has to balance its use of hard and soft power, as well as unilateralism and multilateralism. (Nye 2002)

Discrepancy between American global policy, especially after September 11 and Iraq intervention, and foreign and security policy of the European Union, which has different priorities and means of solving the problems, has already caused problems in the functioning of the transatlantic alliance, and it could cause more problems in the future. (Parsi 2003)

The USA found new allies in Europe in new NATO members, and all new NATO members so far have become members of the EU. In security matters, they are oriented toward the USA and NATO, not towards the EU. The mission in Afghanistan has shown that NATO's geographical area of interest and actions has spread very far from Europe. There is also Darfur mission, where NATO gives its support. NATO also trains and equips Iraqi military personnel, but outside of Iraq, in its training centers. Discrepancy between American military power and the military power of all other allies in NATO has extended 
so much that it poses real difficulties in the functioning of NATO. When we add American unipolarism and its unilateral action in Iraq to this, we can say that NATO will face serious challenges in the future.

After the relative success in South Eastern Europe, the future of NATO could be oriented towards establishing security after the conflict has ended, instead of missions that would be oriented towards conflict prevention or termination. This possibility generates fears because this division of missions between the two sides of Atlantic would leave Europe in a position of cleaning up behind the American military interventions. Without a serious strategic thinking in NATO and the EU, Europe could really face this possibility.

The USA, with couple of its real allies would have a possibility to wage real war when they wanted, and NATO would provide peace making and peace keeping forces and send them to missions outside of Europe. The European Union would be responsible for police forces and society building after a conflict would end and the country was stabilized. A better way would be a balanced responsibility and burden sharing for global security. (Haass 1999)

After September 11, and especially after the Iraq intervention, and all the problems in transatlantic relations and division among the NATO members it has caused, we can say that NATO has again, for the second time after the Cold War, changed itself. Only the formal structure remains the same. Besides including ten new members, huge changes also happened in the internal relations among the allies, in NATO's objectives and missions. The characteristics of this new NATO are now: strong American unipolarism and the pursuing of geopolitical and geostrategic goals outside of NATO, the struggle against terrorism by military means and interventions, deteriorated relations between some of the allies.

After the Istanbul summit, held in 2004, relations between the two sides of the Atlantic have improved, and the USA also realized that it could not follow a completely unipolar policy. The European allies realized that they have to improve their own relations, and not base them on their relation towards American global policy. The situation during the Iraqi crisis, when NATO's functioning was blocked, was one of the results of American unipolar policies. NATO was for a long time considered the most important alliance where the USA participate, and its unity and strength were really weakened and tested because of the transatlantic division over Iraq. The international action that the USA started, through efforts on making an international coalition, ended in a fiasco. American power was at its peak, and its political and moral authority at the bottom. This great division in transatlantic relations threatened to make NATO unimportant, and maybe even redundant, because it would lose its ability to act and the meaning of its existence. (Gvosdev 2002, 2004)

Lacking political unity, the decisiveness of the USA, the political and military weakness of the EU, joined with a slow decision-making process in the field of foreign and security policy, badly influence the possibility of joint actions. These differences are sometimes even described as natural and as something that cannot and would not be changed. (Kagan 2003)

Even if we leave the problems in Asia aside, since they should be out of the scope of transatlantic cooperation, at least two significant strategic challenges lie in front of the allies, and they demand transatlantic cooperation. The first strategic challenge is the transformation of states that are geographically located on the eastern borders of new 
NATO and EU members, from the Baltic Sea to the Balkans. The most important examples are Ukraine's stabilization, improved democratization and stronger orientation to the West, and regime change, democratization and opening of Belarus to the West. The West also has to help Russia to continue its transformation to become a democratic, modern, and western-oriented state, which would also be a strategic partner. The second strategic challenge is the development and implementation of a new strategy towards the states of Caucasus and Central Asia, former Soviet Republics, which face security and political challenges and economic difficulties. The success of the West in integrating the states of Central and Eastern Europe gave a certain hope to those states, that they have a chance for greater cooperation with NATO and the EU. Aspirations of those states should be supported, since the West needs a coherent strategy for the Black and Caspian Sea regions, together with Central Asia.

During the $20^{\text {th }}$ century, Europe was a region where the greatest challenges to international security originated. At the beginning of the $21^{\text {st }}$ century, this region is the broader region of the Middle East, and the biggest threats to the security of the USA and European states and their populations come from there. Therefore, the West has to develop a strategy that would successfully break the current status quo. The West has to be actively involved in the transformation of these societies, so that they would no longer produce ideologies that promote terrorism, but it also has to change its relation towards the sovereignty, independence and natural resources of these states, because they do not belong to the USA or some European state. They belong to the people of the Middle East. A change in the relation of the West to the states of the Middle East and Northern Africa is necessary. By this, we mean that NATO, as a part of the Western community has to change its relationship towards the region. It is doubtful if the USA and Europe can develop a common strategy that is able to respond to these challenges. Today, even the Americans admit that the problems that we have mentioned earlier pose a biggest threat to their common interests, but they do not agree about the way these challenges should be faced. NATO, as a transatlantic security community, and not just a political and military alliance, has to be included in the responses to the security challenges in the contemporary world. These challenges mostly arise in the broader region of the Middle East, which is in geostrategy also called the Arc of instability. But NATO's response must not be identical to the American way of dealing with these problems, which includes the military occupation of independent states and regime changes, according to the will of the American political and military elite.

NATO must not allow itself to become a simple tool for the realization of geopolitical and geostrategic objectives of any state, not even the USA. By becoming a simple tool, NATO would ruin its legitimacy, which could never be restored. If NATO, as an alliance, went for military occupation of Iraq, together with the USA and some of the NATO members, it would have posed an irreversible step towards becoming a sort of "supermarket" of the USA, which would use it for fulfilling its geopolitical and geostrategic objectives. Even in the current situation, NATO permanently suffers from the perception that it is used as a mechanism, which serves for the recovery and stabilization of the states that the USA attack, and occupy.

If the USA wants to change the ways they address the security challenges and respond to those challenges differently, Washington has to express its support to the strong, unified 
and pro-Atlantic Europe, and abandon its policy of dividing the Europe on the Old and New Europe, as former American defense minister Rumsfeld called the two groups of states of Europe 4 . The model of establishing the "coalitions of the willing" and dividing Europe has to fail, there is not any doubt about that. The main dilemma is whether the USA, as the stronger partner in the transatlantic partnership, will show enough willingness to find an acceptable balance between the unilateral pursuit of the American interests and constructive cooperation with allies and institutions in the international arena. Or will the USA simply superimpose its will in the international arena, probably sacrificing the moral authority that it used to have?

If Washington wants Europe to take more responsibility for security, it has to start treating Europe as unified. That kind of Europe could take a real responsibility. The lesson that everybody has to take from the crisis in transatlantic relations is that every attempt of building a unified Europe on the basis of anti-Americanism leads to the division of Europe. American power is a possibility, and not a problem, so it should be used in the right way. (Asmus, 2003)

Europe has to address the problems of current multilateral institutions in a realistic manner. US unilateralism and coalitions of the willing are not the answer. But those Europeans, who insist on the use of the United Nations, at the time when this institution is not capable to fulfill its missions, are also not realistic. In reality, there is a huge disproportion between the problems in the World and the capability of international institutions to resolve them. Therefore, both sides of the Atlantic have to find new solutions, either through building new institutions or through radical reform of the existing ones.

\section{CONCLUSION}

Since the end of the Cold War Era, NATO has undergone a deep internal transformation. From a military and political alliance that faced the possibility of becoming a relic of Cold War, it has become a mixture of an alliance and a security community. By broadening and deepening its activities, objectives and missions and by changing its structure, NATO has adapted itself to the new strategic conditions and realities, so that it can successfully address the security challenges of the contemporary, Post-Cold War Era. By enlarging itself in two rounds, NATO accepted ten new members, and now it has 26 members. Two more states, Albania and Croatia, were invited to join the Alliance at the Summit in Bucharest. The political balance in NATO has shifted towards the USA, consensus as a decision-making rule was seriously put into question, and NATO on the Baltic Sea reached Russian borders. NATO got closer to the regions of Black Sea, Caucasus, encircled the problematic Western Balkans region and created a land bridge towards the regions of the Middle East and Central Asia. The key problem for NATO in the future will be defining its role and position in transatlantic relations, and a challenge that it could become a tool for fulfilling the American geopolitical and geostrategic objectives. If NATO faces this challenge, it must resist the possibility to operate militarily in the interest of the USA, which is mainly oriented towards gaining and keeping control of oil and gas reserves, pipelines and strategic maritime locations. NATO must not also allow itself to become a 
tool that will be used for operations of cleaning and stabilization of states that were the objects of the US military interventions. The lesson of the crisis in relations between the USA and Europe is that the USA and Europe need each other, and NATO is the only institution in military and security field, where representatives of both sides participate and make decisions by reaching a consensus. Therefore, NATO is a necessity. It should not be a NATO as current American official policy would like it to be, but the NATO where the USA and Europe would treat each other as equal partners.

\section{NOTES}

1. By this, we consider the borders of new NATO members that are not borders with the rest of NATO members that are neighbors - so we don't include borders like Bulgarian-Greek border, Bulgarian-Turkish border, Slovenian-Italian border, Poland and Czech Republic borders with Germany etc.

2. Ukraine represents a huge geopolitical gain for NATO or Russia, if they would succeed to pull it into its own bloc. Ukraine is a state divided between its western, pro-European and pro-NATO part and its eastern, pro-Russian part. In less than four years, Ukraine had turbulent changes of government and elections that did not broke the status quo and nevertheless did not resolve the question of Ukraine's foreign policy orientation. At the NATO summit in Bucharest, the USA and some of the allies tried to give Ukraine (together with Georgia) an invitation to the Membership Action Plan (MAP), which represents one step further towards the NATO membership. But the consensus among the allies on the issue could not be reached, mainly because the core European states want to have good relations with Russia, which strongly opposes Ukrainian and Georgian membership in the MAP.

3. The North Atlantic Treaty was signed on April 4, 1949, in Washington, by 12 states, the founders of NATO. The states that founded NATO were: Belgium, Canada, Denmark, France, Iceland, Italy, Luxembourg, The Netherlands, Norway, Portugal, United Kingdom and the United States of America.

4. Rumsfeld used the term Old Europe when he referred to the states in Europe that did not support American intervention and occupation of Iraq. By using the term New Europe, he referred to those NATO and EU members that supported the USA in its unilateral policy. Many of the latter were new members of NATO and EU.

\section{REFERENCES}

Asmus, R., 2002: Opening NATO's Door: How the Alliance remade itself for the New Era, Columbia University Press, New York

Asmus, R., 2003: Rebuilding the Atlantic Alliance, Foreign Affairs, vol. 82, no. 5, pp. 195-203

Aybet, G., 2004: Towards a new transatlantic consensus, NATO Review, vol. 52, no. 3, pp. 120-128

Brown, M. E., 1995: The Flawed Logic of NATO Expansion, Survival, vol. 37, no. 1, pp. 43-51

Brzezinski, Z., 1998: NATO: The Dilemmas of Expansion, In the National Interest, vol. 14, no. 3, pp. 13-17

Carter, A., Perry, W., 1999: Preventive Defense: A New Security Strategy for America, Brookings Institution Press, Washington

Cornish, P., 1996: European Security: The End of Architecture and the New NATO, International Affairs, vol. 72 , no. 4 , pp. $340-368$ 
Petar Kurečić - NATO Enlargement: A "Geopolitical Victory" of the United States in the Post-Cold War Era? Results and Perspectives

Gompert, D., Kugler, R., 1995: Free-Rider Redux: NATO Needs to Project Power (And Europe Can Help), Foreign Affairs, vol. 74, no. 1, pp. 5-12

Gvosdev, N., 2002: The Invisible Alliance? NATO's Future after the Prague Summit, In the National Interest, vol. 1 , no. 10 , pp. 16-21

Gvosdev, N., 2004: Thinking About the Transatlantic Relationship, In the National Interest, vol. 3, no. 17, pp. 1-4

Haass, R. N., 1999: What to Do With American Primacy, Foreign Affairs, vol. 78, no. 5, pp. 170-183

Johnson, C., 2004: The Sorrows of Empire: Militarism, Secrecy and the End of the Republic, Metropolitan Books, New York

Kagan, R., 2003: Of Paradise and Power: America and Europe in the New World Order, New York, Knopf Publishers, New York

Kupchan, C., 2002: The End of the American Era: U. S. Foreign Policy and the Geopolitics of the Twenty-First Century, Knopf Publishers, New York

McCalla, R., 1996: NATO's Persistence After the Cold War, International Organization, vol. 5, no. 3, pp. $445-475$

Mandelbaum, M., 1995: Preserving the New Peace. The Case Against NATO Expansion., Foreign Affairs, Vol. 74, no. 3, pp. 9-13

Mandelbaum, M., 2002: The Inadequacy of American Power, Foreign Affairs, vol. 81, no. 5, pp. 61-73

Nye, J. S., 2002: The Paradox of American Power, Oxford University Press, New York

Parsi, V. E., 2003: The Inevitable Alliance: Europe and the United States Beyond Iraq, Bocconi University Press, Milan

Pfaff, W., 1993: Invitation to War, Foreign Affairs, vol. 72, no. 2, pp. 97-109

Risse-Kappen, T., 1995: Cooperation Among Democracies: The European Influence on US Foreign Policy, Princeton University Press, New York

Risse-Kappen, T., 1996: Collective Identity in a Democratic Community: The Case of NATO, in: Katzenstein, P. (ed.), The culture of national security: Norms and identity in World politics, Columbia University Press, New York, pp. 357-399

Schimmelfennig, F., 2003: The EU, NATO and the Integration of Europe, Cambridge University Press, London

Talbott, S., 2002: From Prague to Baghdad: NATO at Risk, Foreign Affairs, vol. 81, no. 6, pp. 47-50

Walt, S., 1997: Why Alliances Endure or Collapse?, Survival, vol. 39, no. 1, pp. 156-179

Weber, S., 1992: Does NATO have a future? in: Crawford, B. (ed.), The Future of European Security, International and Area Studies Publications, Berkeley, pp. 360-395 
SAŽETAK

\title{
Proširenje NATO-a: Geopolitička pobjeda SAD-a u post hladnoratovskom razdoblju? Rezultati i perspektive
}

\author{
Petar Kurečić
}

\begin{abstract}
Post hladnoratovsko proširenje NATO-a, u dosad provedena dva kruga, predstavlja najveću i najvažniju geopolitičku promjenu u Europi, nakon geopolitičke tranzicije koja se u Europi odigrala u razdoblju od 1989. do 1991. g. Treći krug proširenja, koji uključuje Hrvatsku i Albaniju, otvoren je davanjem pozivnica ovim državama na Summitu NATO-a u Bukureštu u travnju 2008. g. Proširenje je bilo i još uvijek jest dio preobrazbe NATO-a u post hladnoratovskom razdoblju u kojem je NATO evoluirao iz tradicionalnog vojno-političkog saveza u kombinaciju saveza i sigurnosne zajednice. Proširenje je također bilo i jest izraz američke pobjede u hladnom ratu i uzdizanja SAD-a u jedinu svjetsku supersilu. NATO je povećao svoj teritorijalni obuhvat, promijenio svoje misije, sposobnosti i ciljeve, te ih nastavlja mijenjati kako bi ostao spreman odgovoriti na buduće sigurnosne izazove koji se postavljaju pred njegove članice. Najveći izazov NATO-u u budućnosti mogao bi doći iznutra, a to je mogućnost da postane sredstvo američke globalne geostrategije i njenih ciljeva. Ako NATO želi ostati legitimnim savezom i izrastati u sigurnosnu zajednicu, ne smije postati sredstvo za ispunjavanje geopolitičkih i geostrateških ciljeva samo jedne države, pa čak ni SAD-a. Stoga je u odnosima SAD-a i Europe potreban uravnotežen pristup, prema kojem SAD ne bi koristile vojnu moć kako bi nametale svoje geopolitičke i geostrateške ciljeve pod svaku cijenu.
\end{abstract}

Received (Primljeno): 2007 - 11 - 30

Accepted (Prihvaćeno): 2008 - 03 - 20

Mr. sc. Petar Kurečić, savjetnik

u Hrvatskom Saboru,

Trg sv. Marka 7, 10000 Zagreb e-mail: petar.kurecic@sdp.hr 